\title{
Risk factors associated with actinic prurigo: a case control study ${ }^{*}$
}

\author{
Juan Carlos Cuevas-Gonzalez ${ }^{1}$ \\ Socorro Aída Borges-Yáñez ${ }^{3}$
}

\author{
María Elisa Vega-Memíje $\mathrm{e}^{2}$ \\ Erika Rodríguez-Lobato ${ }^{2}$
}

DOI: http:/ / dx.doi.org/10.1590/abd1806-4841.20175105

\begin{abstract}
BACKGROUND: Actinic prurigo (AP) is an idiopathic photodermatosis. Although its initial manifestations can appear in 6 to 8-year-old children, cases are diagnosed later, between the second and fourth decades of life, when the injuries are exacerbated.

Oвјестіvе: To identify risk factors associated with clinical manifestations of AP such as skin and mucosal lesions.

MetHODs: Thirty patients with AP and 60 controls were included in the study, the dependent variable was the presence of skin or labial mucosal lesions, the independent variables were age, sex, solar exposure, living with pets or farm animals, exposure to wood smoke, smoking habit, years smoking, and hours spent per day and per week in contact with people who smoke.

RESULTS: Of the 30 diagnosed AP patients, 66.7\% were female. Patients age ranged from 7 to 71 years and the mean age was $35.77 \pm 14.55$ years. We found significant differences with the age and cohabitation with farm animals. Those who lived with farm animals presented 14.31 times higher probability of developing AP (95\% CI 3-78.06).

STUDY LIMITATIONS: This is a case-control study; therefore, a causal relationship cannot be proven, and these results cannot be generalized to every population.

Conclusions: The identification of factors related to the development of AP increases our knowledge of its physiopathology. Moreover, identifying antigens that possibly trigger the allergic reaction will have preventive and therapeutic applications in populations at risk of AP.
\end{abstract}

Keywords: Lip; Photosensitivity disorders; Risk factors; Skin

\section{INTRODUCTION}

Actinic prurigo (AP) is an idiopathic photodermatosis that primarily affects skin that has been exposed to sunlight and, to a lesser extent, the labial and conjunctival mucosa. AP also develops in areas that are not sun-exposed. It is more common in dark-skined population with a significant Amerindian component due to miscegenation. AP appears most often in the first decade of life, but it can develop at any age, primarily in women and people with dark skin who live in a dry and sunny climates at altitudes higher than 1000 meters above sea level. However, some cases have been described at lower altitudes. ${ }^{1,23}$

Miscegenation is a racial factor with a significant role in the development of $\mathrm{AP}^{4}$ In Mexico, the prevalence of $\mathrm{AP}$ is 3.9\%, and this disease has been linked to the human leukocyte antigen (HLA), particularly the HLA-DR4 allele, which varies among populations. 5,6 In Mexico, from $90 \%$ to $92.8 \%$ of patients with AP harbor this al- lele, of which HLA-DRB1 * 0407 is the most common subtype $(60 \%$ to $80 \%) .1,5,7-10$

The pathogenesis of AP is mediated by interleukin-2 (IL2); the presence of $\mathrm{T}$ lymphocytes in peripheral blood which are part of the Th1 response; tumor necrosis factor alpha (TNF- $\alpha$ ); macrophages, and the induction of apoptosis as the last step in the type IV hypersensitivity reaction. ${ }^{3,11-14}$ In addition, elements of the type IV hypersensitivity subtype b response have been observed in AP, such as elevated levels of serum IgE and the presence of mast cells, macrophages, and B lymphocytes. ${ }^{13-15}$

Although the initial manifestations of AP appear in 6 to 8 -year-old children, cases are diagnosed later (from the second to the fourth decade of life), once the lesions are exacerbated..$^{2.3} \mathrm{AP}$ is more common in women, by a 2:1 ratio, and primarily affects people with dark skin types (Fitzpatrick classification IV and V) who

\footnotetext{
Received on 06.09.2015.

Approved by the Advisory Board and accepted for publication on 04.08.2016.

Work performed at the Dermatology Department, Hospital General Dr. Manuel Gea González, Mexico City, Mexico.

Financial support: None.

Conflict of interest: None

Department of Stomatology, Institute of Biomedical Sciences, Autonomous University of Ciudad Juárez , Juárez City, Chihuahua, Mexico.

Dermatology Department, Hospital General Dr. Manuel Gea González, Mexico City, Mexico.

Department of Dental Public Health DEPeI Faculty of Dentistry, Universidad Nacional Autónoma de México, Mexico City, Mexico.

C2017 by Anais Brasileiros de Dermatologia
} 
live in dry and sunny climates. ${ }^{2,3,10,16}$ Ultraviolet A and B rays have proven to trigger the pathogenesis of AP in a genetically determined manner, but it is unclear why only certain populations develop the disease. Thus, it can be hypothesized that other risk factors associated with AP do in fact exist.

Searching for risk factors that are linked to AP, Vera et al. ${ }^{17}$ conducted a pilot study between 1990 and 2006 in the Dr. Manuel Gea González General Hospital, which is the main referral center for patients with AP in Mexico. They found (in patients who received medical care in the Department of Dermatology) that patients who had a history of exposure to wood smoke presented a 9.5 times greater probability of developing AP, as compared to 3.6 times of those who lived with domestic animals and 6.9 times in people who lived with farm animals. ${ }^{17}$ Thus, we examined these variables to identify the risk factors associated with the clinical presence of skin and mucosal lesions in patients with AP.

\section{METHODS}

This is a case control study. Thirty patients were recently diagnosed with AP due to their clinical features, where the diagnosis was confirmed by histopathology. We included 60 controls (clinically healthy subjects) who visited the dentistry and orthodontics department at the same hospital. The studied population in both departments had the same demographic characteristics. All patients that agreed to participate voluntarily in the study signed an informed consent form.

A questionnaire to identify risk factors was developed, including 82 items. The data collection instrument was validated using a test-retest to eliminate unclear or confusing questions and obtained a Cronbach's alpha of 0.83 .

Based on the literature in which exposure to wood smoke and cohabitation with domestic pets and farm animals were reported, we calculated the sample using Power Analysis and Sample Size [PASS, with the formula: $\mathrm{N} 1=(\mathrm{z} 1-\alpha / 2+\mathrm{Z} 1-\beta) 2 / \mathrm{C}(\mathrm{r}) 2+3)$ ], with a confidence level of $95 \%, 80 \%$ of power, a two tailed test with alpha levels of 0.05 , and an odds ratio of 4 for the dependent variable AP. ${ }^{17}$

The calculated sample size was 17 cases and 17 controls. The final version of the instrument was applied to the total available sample, which included 30 cases and 60 controls.

\section{Study variables}

The dependent variable was AP (presence of skin or labial mucosal lesions), and the lesions were diagnosed by histopathology, using the criteria described by Vega in $1993^{18}$ (presence of hyperkeratosis, acanthosis, spongiosis, vacuolation of the basal layer, angiogenesis, eosinophils, melanophages and diffuse nodular lymphocytic infiltrate in skin lesions, and the formation of lymphoid follicles in lip injuries). The independent variables were age, sex (male/female), level of education, sunlight exposure (hours per day and per week), living with domestic pets or farm animals (hours per day and per week of continuous cohabitation), exposure to wood smoke (hours per day and per week of exposure), smoking history (in smokers, number of cigarettes smoked per day and per week; in former smokers, years smoking, number of cigarettes smoked per day and per week, years since quitting smoking; and in passive smokers, hours spent per day and per week in contact with people who smoke). In all cases, participants were asked about prior and current exposure to risk factors.

\section{Bivariate analysis}

The following variables were analyzed: exposure to sunlight in daily activities, number of hours and days per week of exposure, years dedicated to the current occupational activity, living with pets, number of years owning pets, days in contact with the pet, living with farm animals, number of years having farm animals, days per week in contact with farm animals, use of firewood for cooking, hours per day and per week of exposure to wood smoke, number of years spent cooking with firewood, number of cigarettes smoked per day and per week, number of years smoking, number of cigarettes smoked per day and per week, number of years without smoking, and number of hours spent per day and per week in contact with people who smoke.

Normality tests were performed (Shapiro-Wilk); a chisquared test was used for qualitative variables; and Kruskal-Wallis test was applied for variables with asymmetric distribution. Significance level $=0.05$

\section{Logistic regression}

The criteria used to incorporate variables in the multivariate model were: those variables that showed statistically significant differences in the previously performed bivariate comparisons $(\mathrm{p}$ $<0.25$ ) and variables considered particularly important (related to the dependent variable). The backward model was used, in which all of the variables were incorporated at first and then one by one if they satisfied previously established conditions, until no more variables could be removed. The variables that remained are responsible for the changes in the dependent variable.

The variables included in the initial model were sex, age, living in contact with domestic animals, living in contact with farm animals, what is used to cook at home, number of days per week of sun exposure, and number of cigarettes smoked per week.

The variables included in the final model were age, living in contact with farm animals, what is used to cook at home, number of days per week of sun exposure, and number of cigarettes smoked per week.

The database and the statistical analysis were performed using the Statistical Package (SPSS), version 18.0 (SPSS Inc., Chicago, IL, USA).

\section{RESULTS}

Of the 30 recently diagnosed AP patients, $66.7 \%$ were female. Patient's age ranged from 7 to 71 years, and the mean age was $35.77 \pm 14.55$ years.

Seventy percent of the control group were women, and the age of control subjects ranged from 9 to 65 years; the average age was $38.22 \pm 13.14$ years.

Forty-three percent of cases were within the 7 to 25 -yearold range, $40.3 \%$ were between 26 and 46 years of age, and $16.7 \%$ were older than 47 . The percentages of controls were $15 \%, 53.3 \%$, and $31.7 \%$, respectively. 
Forty percent of cases and $55 \%$ of controls had lived in their current residence for 17-36 years. The maximum education level was high school in $56.7 \%$ of the cases and $58.3 \%$ of the controls.

Ninety percent of the cases reported sunlight exposure in their daily activities, as compared to $61.7 \%$ of the controls, and those who were exposed to sunlight in their daily activities presented a 4.59 times higher probability of developing AP than did individuals who were not exposed ( $p=0.005,95 \%$ CI 1.52-20.55) (Table 1). More-

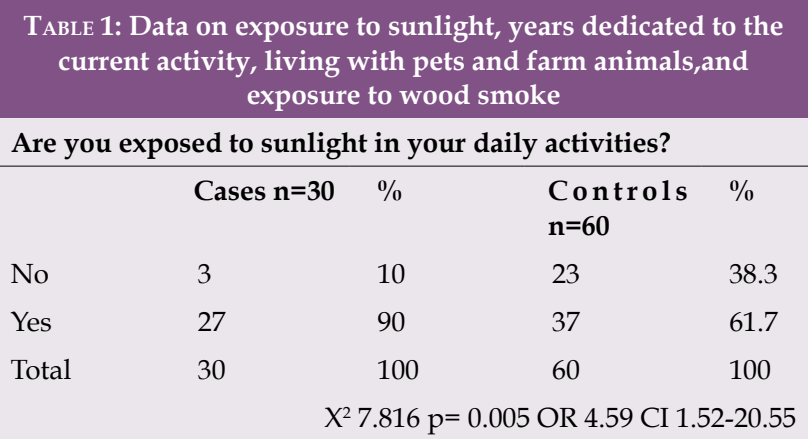

Years performing the same activity

\begin{tabular}{|c|c|c|c|c|}
\hline & Cases $n=30$ & $\%$ & $\begin{array}{l}\text { Controls } \\
n=60\end{array}$ & $\%$ \\
\hline $1-5$ years & 18 & 60 & 16 & 26.6 \\
\hline 6-19 years & 10 & 33.3 & 22 & 36.7 \\
\hline 20 years & 2 & 6.7 & 22 & 36.7 \\
\hline & 30 & 100 & 60 & 100 \\
\hline
\end{tabular}

Do you have domestic pets?

$$
\text { Cases } \mathbf{n}=\mathbf{3 0} \%
$$

$\begin{array}{lcccc}\text { No } & 10 & 33.3 & 37 & 61.7 \\ \text { Yes } & 20 & 66.7 & 23 & 38.3 \\ \text { Total } & 30 & 100 & 60 & 100 \\ & & \mathrm{X} 26.435 \mathrm{p}=0.011 \text { OR } 2.21 \text { IC } 1.28-8.07\end{array}$

Do you have farm animals?

$$
\text { Cases } \mathbf{n}=\mathbf{3 0} \%
$$

$\begin{array}{lllll} & 18 & 60 & 57 & 95 \\ \text { Yes } & 12 & 40 & 3 & 5\end{array}$

$\begin{array}{lllll}\text { Total } & 30 & 100 & 60 & 100\end{array}$

$X^{2} 17.640 \mathrm{p}=0.001$ OR 11.66 IC $3.21-49.93$

At home, what do you use to cook?

Cases $\mathbf{n}=30 \quad \%$

Butane gas 17

Firewood 13

Total

30

3

56.7

Controls \% $n=60$

$50 \quad 83.3$

$\begin{array}{lll}43.3 & 10 & 16.7\end{array}$

$100 \quad 60 \quad 100$

$X^{2} 7.47 p=0.006$ OR 2.82 IC $1.41-10.30$ over, $60 \%$ of cases spent $1-5$ years performing the same activity, as compared to $26.6 \%$ of controls, $36.7 \%$ of controls were $6-19$ years of age, and another $36.7 \%$ were older than 20 ( $p=0.002)$.

In the bivariate analysis, $66.7 \%$ of the patients had pets, as compared to $38.3 \%$ of the controls. People who lived with domestic pets presented a 2.21 times higher probability of developing AP ( $p=0.011,95 \%$ CI 1.28-8.07).

Forty percent of the cases lived with farm animals, as compared to $5 \%$ of the controls. People who lived with farm animals presented a 11.66 times higher probability of developing AP versus those who did not ( $p=0.001,95 \%$ CI 3.21-49.93).

Furthermore, $43.3 \%$ of the cases and $16.7 \%$ of the controls used wood for cooking and heating their homes; subjects who cooked with wood presented a 2.82 times higher probability of developing AP than those who did not ( $p=0.006,95 \%$ CI 1.41-10.30).

No statistically significant differences were observed in the following variables: years living in their current residence (336 years; $\left.X^{2}=3.73, p=0.154\right)$, performing outdoor work activities ( $66.7 \%$ of the patients had dermatosis versus $28.3 \%$ of the controls; $\mathrm{X}^{2}=.238, \mathrm{p}=0.626$ ), performing outdoor activities before their current occupation $\left(66.7 \%\right.$ of the cases vs $21.7 \%$ of the controls; $\mathrm{X}^{2}=$ .1.431, $\mathrm{p}=0.232)$, total hours of sunlight exposure per week $(43.3 \%$ of the patients exposed to sunlight for more than 3 hours had AP vs $61.7 \%$ of the controls; $16.7 \%$ of the patients exposed for 21 hours or more had AP vs $13.3 \%$ of the controls; $\left.X^{2}=1.214, p=0.545\right)$, sunlight exposure in previous work activities (43.3\% of the cases vs $35 \%$ of the controls ; $\left.X^{2}=0.591, p=0.442\right)$, location where the pet stayed during the day and night ( $36.4 \%$ of the cases confirmed that the pet remained inside the house during the day; $\mathrm{X}^{2}=.414, \mathrm{p}=0.520, \mathrm{X}^{2}$ $=0.102)$, owning farm animals $(33.33 \%$ of the cases vs $18.3 \%$ of the controls ; $\left.X^{2}=2.516, p=0.113\right)$, and exposure to wood smoke inside or outside the house $(92.3 \%$ of the cases and $80 \%$ of the controls were exposed to outdoor wood smoke; $\left.X^{2}=0.755, p=0.385\right)$. The results of the nonparametric tests are shown in table 2 .

In the logistic regression, we found significant differences when analyzing the variables of age and living with farm animals (Table 3). Those who lived with farm animals presented a 14.31 times higher probability of developing AP (95\% CI 3-78.06)].

\section{DISCUSSION}

In addition to ultraviolet radiation (UVB-UVA), which has been widely described as a factor that triggers $\mathrm{AP}$, there are other risk factors, such as age and living with farm animals, that can trigger the allergic reaction.

The questionnaire on risk factors, developed by our research team, allowed us to collect information about current and previous exposures, in which $60 \%$ of the cases had carried out their current activities for up to 5 years. Patients with AP change their activity more often than controls and they are more exposed to sunlight $(p=0.002)$. Before patients are diagnosed, their lesions are acute. After diagnosis, an explanation is given to them, and they are told to protect themselves using physical barriers and sunscreens. Consequently, injuries can be reverted, and in some cases, disappear for long periods due to low exposure to solar radiation. 
TABLE 2: Comparison between cases and controls (Kruskal-Wallis analysis), variables with asymmetric distribution

\begin{tabular}{|c|c|c|c|}
\hline Variables & $\begin{array}{l}\text { Case/ } \\
\text { Control }\end{array}$ & $\begin{array}{l}\text { Percentile } \\
25 / 50 / 75\end{array}$ & $\begin{array}{l}\text { Asymptotic you. } \\
\%\end{array}$ \\
\hline How many years have you performed this activity? & $\begin{array}{c}\text { Control } 60 \\
\text { Case } 30 \\
\text { Total } 90\end{array}$ & $\begin{array}{l}5 / 15 / 26 \\
3 / 4 / 16\end{array}$ & 0.003 \\
\hline How many days per week are you exposed to sunlight? & $\begin{array}{c}\text { Control } 60 \\
\text { Case } 30 \\
\text { Total } 90\end{array}$ & $\begin{array}{l}0 / 3.5 / 7 \\
2.75 / 7 / 7\end{array}$ & 0.006 \\
\hline $\begin{array}{l}\text { How many hours per day are you exposed to sunlight in your work } \\
\text { activities? }\end{array}$ & $\begin{array}{c}\text { Control } 60 \\
\text { Case } 30 \\
\text { Total } 90\end{array}$ & $\begin{array}{l}1 / 2 / 4.75 \\
1 / 3 / 6.2\end{array}$ & 0.657 \\
\hline How many days per week are you exposed to sunlight? & $\begin{array}{c}\text { Control } 60 \\
\text { Case } 30 \\
\text { Total } 90\end{array}$ & $\begin{array}{c}0 / 0 / 5 \\
0 / 0 / 6.2\end{array}$ & 0.367 \\
\hline How many hours per week are significance exposed to sunlight? & $\begin{array}{c}\text { Control } 60 \\
\text { Case } 30 \\
\text { Total } 90\end{array}$ & $\begin{array}{c}0 / 2 / 6 \\
4 / 4.50 \\
16.2\end{array}$ & 0.177 \\
\hline How many years have you had pets? & $\begin{array}{c}\text { Control } 60 \\
\text { Case } 30 \\
\text { Total } 90\end{array}$ & $\begin{array}{c}0 / 0 / 2 \\
0 / 1 / 6.2\end{array}$ & 0.069 \\
\hline How many days per week are you in contact with your pet? & $\begin{array}{c}\text { Control } 60 \\
\text { Case } 30 \\
\text { Total } 90\end{array}$ & $\begin{array}{l}0 / 0 / 7 \\
0 / 7 / 7\end{array}$ & 0.006 \\
\hline $\begin{array}{l}\text { How many hours per day do you spend in physical contact with your } \\
\text { pet? }\end{array}$ & $\begin{array}{c}\text { Control } 60 \\
\text { Case } 30 \\
\text { Total } 90\end{array}$ & $\begin{array}{l}0 / 0 / 1 \\
0 / 1 / 1\end{array}$ & 0.045 \\
\hline How many days per week are you in contact with farm animals? & $\begin{array}{l}\text { Control } 3 \\
\text { Case } 12 \\
\text { Total } 15\end{array}$ & $\begin{array}{l}1 / 1 / 7 \\
1 / 7 / 7\end{array}$ & 0.187 \\
\hline $\begin{array}{l}\text { How many hours per day do you spend in physical contact with farm } \\
\text { animals? }\end{array}$ & $\begin{array}{c}\text { Control } 11 \\
\text { Case } 10 \\
\text { Total } 21\end{array}$ & $\begin{array}{l}4 / 7 / 7 \\
1 / 6 / 7\end{array}$ & 0.583 \\
\hline $\begin{array}{l}\text { How many days per week are you exposed to smoke from wood or } \\
\text { charcoal? }\end{array}$ & $\begin{array}{c}\text { Control } 10 \\
\text { Case } 13 \\
\text { Total } 23\end{array}$ & $\begin{array}{l}1 / 1.5 / 7 \\
3 / 7 / 7\end{array}$ & 0.058 \\
\hline $\begin{array}{l}\text { How many hours per day are you exposed to smoke from wood or } \\
\text { charcoal? }\end{array}$ & $\begin{array}{c}\text { Control } 10 \\
\text { Case } 13 \\
\text { Total } 23\end{array}$ & $\begin{array}{l}1 / 3 / 7 \\
1 / 3 / 7\end{array}$ & 0.001 \\
\hline How many hours per day are you exposed to tobacco smoke? & $\begin{array}{c}\text { Control } 10 \\
\text { Case } 13 \\
\text { Total } 23 \\
\end{array}$ & $\begin{array}{l}1 / 2.5 / 7 \\
1 / 1 / 7\end{array}$ & 0.565 \\
\hline
\end{tabular}

\begin{tabular}{cclcc}
\multicolumn{4}{c}{ TABLE 3: Logistic regression model } \\
\hline Variable & OR & \multicolumn{2}{c}{$\begin{array}{c}95 \% \text { CI } \\
\text { Inferior Superior }\end{array}$} & $\begin{array}{c}\text { Signifi- } \\
\text { cance }\end{array}$ \\
\hline Age & 0.956 & 0.918 & 0.996 & 0.031 \\
Living with farm animals & 14.31 & 3.00 & 78.06 & 0.001 \\
\hline
\end{tabular}

Variables used in the model: age, living with farm animals, fuel used to cook at home, days per week of sunlight exposure, and cigarettes smoked per week.

A study that reported the sociodemographic profiles of 20-year-old patients with AP found that part of this population engaged in work activities that necessarily required sunlight exposure. ${ }^{19}$ Although it is not possible to completely avoid such radiation, good results are obtained in reducing lesions with preventive care.

Generally, the first manifestations of AP occur during childhood, but patients are often diagnosed later. ${ }^{2,3}$ In our study, the mean age of diagnosis was $35.77 \pm 14.55$ years. At the time of the interview, patients reported that the first lesion appeared on the skin or lip in childhood, and since then, they had not sought any medical consultation. None patients reported that their injuries had been recently formed. This is consistent with the results of logistic regression in which the likelihood of developing actinic prurigo decreases with age ( $p=0.031$, OR 0.956).

Our results are consistent with those of Vera et al., who reported a significantly higher risk of AP (14.31 times in our study) in patients who lived with farm animals, as compared to the controls ( $p=0.001,95 \%$ CI 3.00-78.06). ${ }^{17}$ Based on these findings, we hypothesize that poor hygiene, as well as exposure to animal bacteria and parasites, is a risk fator can develop this disease.

Exposure to bacteria, fungi, and parasites can cause primary or secondary skin infections. Although these infections can develop in people engaged in any activity, certain professions, such as 
animal keepers, farmers, and breeders are at risk due to higher exposure, supporting the hypothesis that AP is a type IV hypersensitivity reaction to microbial agents (viruses, fungi, and parasites)..$^{20,21}$ Further follow-up studies are warranted in those who perform the aforementioned activities to examine these theories and obtain conclusive results.

One limitation of this study is that it is a case-control study; therefore, a causal relationship cannot be proven, and these results cannot be generalized to every population. Another limitation is that these cases and controls were not matched by sex and age and, according to some confidence intervals, the sample size must be increased. On the other hand, an advantage of this study is that it is one of the first studies of its kind to examine these associations.
This study, therefore, contributes to the identification of risk factors associated with AP. These results can also guide the development of studies with powerful methodologies.

\section{CONCLUSIONS}

The identification of factors related to AP increase one's knowledge regarding AP physiopathology. The discovery of antigens that possibly trigger the allergic reaction will have preventive applications in populations at high risk of developing AP. Patients and parents must become aware of the cares to take when minors are diagnosed with this disease. People diagnosed with AP must adhere to the treatment to avoid the worsening of their lesions.

\section{REFERENCES}

1. Salazar AM. Prurigo actínico en la niñez. Dermatol Pediatr Lat. 2005;3:193-200.

2. Hojyo-Tomoka T, Vega-Memije E, Granados J, Flores 0, Cortés-Franco R, Teixeira F, et al. Actinic prurigo: an update. Int J Dermatol. 1995;34:380-4.

3. Arrese JE, Dominguez-Soto L, Hojyo-Tomoka MT, Vega-Memije E, Cortés-Franco $R$, Guevara $E$, et al. Effectors of inflammation in actinic prurigo. J Am Acad Dermatol. 2001;44:957-61.

4. Saeb-Lima M, Cortés-Franco R, Vega-Memíje ME, Hojyo-Tomoka MT, GuevaraSanguines ME, Domínguez-Soto L. Principales fotodermatosis en Latinoamérica. Revisión y actualización. Derm Venez. 1999;37:15-21.

5. Wiseman MC, Orr PH, Macdonald SM, Schroeder ML, Toole JW. Actinic prurigo: clinical features and HLA associations in a Canadian Inuit population. J Am Acad Dermatol. 2001:44:952-6.

6. Granados J, Domínguez L. Inmunogenética del Prurigo Actinico en mexicanos. Dermatol Rev Mex. 1993;37:314-5.

7. Vega-Memije ME, Mosqueda-Taylor A, Irigoyen-Camacho ME, Hojyo-Tomoka MT, Domínguez-Soto L. Actinic prurigo cheilitis: clinicopathologic analysis and therapeutic results in 116 cases. Oral Surg Oral Med Oral Pathol Oral Radiol Endod. 2002:94:83-91.

8. Hojyo-Tomoka T, Granados J, Vargas-Alarcón G, Yamamoto-Furusho JK, VegaMemije $E$, Cortés-Franco R, et al. Further evidence of the role of HLA-DR4 in the genetic susceptibility to actinic prurigo. J Am Acad Dermatol. 1997:36:935-7.

9. Grabczynska SA, McGregor JM, Kondeatis E, Vaughan RW, Hawk JL. Actinic prurigo and polymorphic light eruption: common pathogenesis and the importance of HLA-DR4/DRB1*0407. Br J Dermatol. 1999;140:232-6.

10. Hojyo-Tomoka MT, Vega-Memije ME, Cortes-Franco R, Domínguez-Soto L. Diagnosis and treatment of actinic prurigo. Dermatol Ther. 2003;16:40-4.

11. Umaña A, Gómez A, Durán MM, Porras L. Lymphocyte subtypes and adhesion molecules in actinic prurigo: observations with cyclosporin A. Int J Dermatol. 2002:41:139-45

12. Moncada B, González-Amaro R, Baranda ML, Loredo C, Urbina R Immunopathology of polymorphous light eruption. T lymphocytes in blood and skin. J Am Acad Dermatol. 1984 :10:970-3.

13. Martínez-Luna E, Bologna-Molina R, Mosqueda-Taylor A, Cuevas-González JC, Rodríguez-Lobato E, Martínez-Velasco MA, et al. Inmunohistochemical detection of mastocytes in tissue from patients with actinic prurigo. J Clin Exp Dent. 2015;7:656-9

14. Cuevas-Gonzalez JC, Lievanos-Estrada Z, Vega-Memije ME, Hojyo-Tomoka MT, Dominguez-Soto L. Correlation of serum IgE levels and clinical manifestations in patients with actinic prurigo. An Bras Dermatol. 2016;91:23-6.

15. Rodríguez-Carreón AA, Rodríguez-Lobato E, Rodríguez-Gutiérrez G, CuevasGonzález JC, Mancheno-Valencia A, Solís-Arias MP, et al. Actinic Prurigo. Skinmed. 2015;13:287-95.

16. Sachdeva S. Fitzpatrick skin typing: applications in dermatology. Indian J Dermato Venereol Leprol. 2009;75:93-6.

17. Vera Izaguirre DS, Zuloaga Salcedo S, González Sánchez PC, Sánchez Lara K Chávez Tapia N, Hojyo Tomoka MT, et al. Actinic prurigo: a case-control study of risk factors. Int J Dermatol. 2014:53:1080-5.

18. Vega ME. Características histopatológicas del prurigo actínico. Dermatol Rev Mex. 1993; 37:295-297.

19. Cuevas-González JC, Rodríguez-Lobato E, Mancheno-Valencia A, Hojyo-Tomoka MT, Domínguez-Soto L, Vega-Memíje ME. Prurigo actínico; perfil demográfico de los últimos 20 años en la División de Dermatología del Hospital General Dr. Manuel Gea González en la Ciudad de México. Dermatol Rev Mex. 2014; 58:508-13.

20. Cso.go .cr [Internet]. Durocher LP. Enfermedades de la piel. Enciclopedia de salud de salud y seguridad en el trabajo. [Acceso 08 Ago 2015]. Disponible: www.cso. go.cr/tematicas/higiene/enciclopedia/08 enfermedades piel.pdf

21. Cotran RS, Kumar V, Collins T. Patología Estructural y Funcional. 6. ed. Mexico: McGraw-Hill Interamericana; 2000.

How to cite this article: Cuevas-Gonzalez JC, Vega-Memíje ME, Borges-Yáñez SA, Rodríguez-Lobato E. Risk factors associated with actinic prurigo: a case control study. An Bras Dermatol. 2017;92(6): 774-8. 